\title{
DA INSUFICIÊNCIA DE FUNDAMENTAÇÁO DO STF PARA EFEITOS PROSPECTIVOS DA INCONSTITUCIONALIDADE DE BENEFÍCIOS FISCAIS IRREGULARES DE ICMS
}

\author{
Rafael Gonçalves de Lima \\ $\overline{\text { Centro de Estudos em Direito e Negócios (CEDIN) }}{ }^{1}$ \\ Artigo recebido em: 31/01/2021. \\ Artigo aceito em: 14/06/2021.
}

\section{Resumo}

O objetivo do presente trabalho foi analisar - de modo exemplificativo utilizando do método indutivo de pesquisa -, decisóes da Suprema Corte que modularam os efeitos de decisões que declararam a inconstitucionalidade de leis estaduais que concederam benefício fiscal de ICMS com a ausência de convênio interestadual. Com isso, foi possível demonstrar que tais decisóes judiciais no âmbito da Suprema Corte carecem da devida fundamentação no que tange à limitação dos efeitos temporais, de modo que se mostra incons- titucional a mera citação da segurança jurídica ou do excepcional interesse social. Assim, concluiu-se que é necessário trazer argumentos mais fundamentados, de modo claro e padronizado (na medida do possível), uma vez que a modulação dos efeitos temporais é mecanismo excepcional no ordenamento jurídico, em nome da segurança jurídica.

Palavras-chave: efeitos temporais; inconstitucionalidade; modulação; segurança jurídica.

1 Pós-graduando em Direito Internacional pelo Centro de Estudos em Direito e Negócios (CEDIN). Especialista em Direito Tributário pelo Centro de Estudos em Direito e Negócios (CEDIN). Graduado em Direito pela Escola Superior Dom Helder Câmara (ESDHC). Foi membro do Grupo de Pesquisa "Direito Internacional dos Recursos Naturais - DIRNAT” da Escola Superior Dom Helder Câmara (ESDHC). Exerce função na Diretoria de Gestão de Compras e Licitaçôes (DGCL) do Ministério Público de Minas Gerais. Foi estagiário do Ministério Público do Trabalho, lotado no $24^{\circ}$ Ofício Geral da PRT3. Possui experiência profissional na área contábil, mais direcionada às linhas trabalhista e previdenciária. ORCID: https://orcid.org/0000-0002-1863-7611 / e-mail: rafagoncalvesdelima@hotmail.com 


\section{THE INSUFFICIENCY OF FOUNDATION OF STF FOR PROSPECTIVE EFFECTS OF THE INCONSTITUTIONALITY OF ICMS IRREGULAR FISCAL BENEFITS}

\section{Abstract}

The objective of this work was to analyze - exemplary - (through the inductive research method), Supreme Court decisions which modulated the effects of decisions that declared unconstitutional state laws that granted tax incentive on I.C.M.S. without interstate agreement. Thereby, it was possible to evince that such Supreme Court decisions lack the proper reasoning regarding the temporal effects limitation, so that becomes unconstitutional the mere mention of legal certainty or exceptional social interest. Thus, it turns out that it is necessary to bring more substantiated arguments, in a clear and standardized way (as far as possible), whereas the temporal effects modulation is an exceptional mechanism in legal system, considering legal certainty.

Keywords: legal certainty; modulation. temporal effects; unconstitutionality. 


\section{Introdução}

Compreende-se que o controle de constitucionalidade constitui premissa necessária para entender o funcionamento do ordenamento jurídico. E no que tange especificamente ao Direito Tributário, é de suma importância a harmonia das normas infraconstitucionais com a Constituição da República de 1988, uma vez que o tributo constitui grande receita aos cofres públicos. Assim, já foram tomadas decisóes na Suprema Corte que consideraram inconstitucionais as normas estaduais que concederam unilateralmente benefícios fiscais no âmbito do ICMS, pois eivadas de vícios, haja vista que careceram de convênio interestadual no Conselho Nacional de Política Fazendária (CONFAZ). Isso posto, a Suprema Corte, em determinadas situaçóes, modulou os efeitos temporais das decisóes, de modo a não retroagir desde a origem da norma estadual, sob argumento de resguardar determinados princípios de Direito. Contudo, a fundamentação de tais modulaçóes nem sempre atendeu aos ditames constitucionais para fins de fundamentação, conforme será demonstrado adiante.

\section{Breves consideraçóes sobre o controle de constitucionalidade brasileiro}

É inegável a relevância da Constituição em nosso ordenamento jurídico, uma vez que ela ilumina todas as demais normas e atos do poder público. Nesse sentido, e considerando a teoria pura do direito capitaneada por Hans Kelsen, ao defender que as demais normas derivam seu fundamento de validade da lei maior, esse status superior foi validado pela doutrina de princípio da supremacia constitucional.

Sendo assim, torna-se necessário um sistema eficaz que avalie a compatibilidade entre as normas infraconstitucionais e a norma constitucional, a fim de que possa ser mantida a harmonia do ordenamento jurídico brasileiro, e privilegiada, em todos os momentos, a Constituição, como norma fundamental.

Em decorrência do princípio da supremacia constitucional, advém o controle de constitucionalidade, que, conforme leciona Barroso (2009), é parte integrante da jurisdição constitucional.

Outrossim, interessante trazer ao debate as acepçóes de Bonavides (1999) que atribui à superioridade da norma constitucional o fato dela advir do poder constituinte, em face dos poderes constituídos. E, considerando que as constituiçôes rígidas demandam um procedimento solene de revisão - diverso das normas infraconstitucionais -, não há como negar o fenômeno da supremacia 
constitucional, formando verdadeira hierarquia no arcabouço normativo.

Ao tratar do controle de constitucionalidade, Bulos leciona que

[...] o fundamento basilar do controle de constitucionalidade é a proteçáo dos direitos e garantias fundamentais, porque existe uma tábua de valores na sociedade que deve ser preservada das injunçôes estritamente políticas, das decisōes que contrariam a legitimidade democrática, dos conchavos que deturpam as conquistas alcançadas no longo e tormentoso processo de elaboração originária da constituição. Daí o combate a atos inconstitucionais do Poder Público, mediante controle de constitucionalidade (BULOS, 2017, p. 177).

Assim, prima facie, ao declarar a inconstitucionalidade de determinada norma, estaria o Poder Judiciário agindo em defesa da hierarquia das normas constitucionais.

Conforme defendido pela doutrina constitucionalista a que se teve acesso neste trabalho, o controle de constitucionalidade brasileiro, levando em consideração os órgãos responsáveis, é misto, híbrido e eclético, pois se apresenta dividido em controle político e controle jurisdicional. O primeiro é exercido pelos poderes Legislativo e Executivo, em algumas situaçôes delimitadas pela Constituição da República de 1988. Já o segundo se subdivide em controles difuso e concentrado.

No controle de constitucionalidade difuso há a aplicação pelos órgãos jurisdicionais competentes, do direito ao caso concreto. Oriundo do sistema norte-americano, do julgamento do famoso caso Marbury versus Madison, o controle difuso é percebido constantemente em nosso cotidiano. Ao lecionar as contribuiçôes do sistema de controle de constitucionalidade americano, Bulos (2017, p.178) aponta que "[...] qualquer juiz pode averiguar a alegação de inconstitucionalidade, diante do caso concreto, na via de defesa ou de exceção", e que "a fiscalização da constitucionalidade é necessária quando, no curso de qualquer ação judicial, uma das partes pretende aplicar a lei, mas a outra defende-se dessa pretensão”.

Ao revés, o controle de constitucionalidade concentrado, de fato concentra em um único Tribunal Constitucional a interpretação conforme a constituição, pois atua em via abstrata, com foco na norma ou ato impugnados, afastados da justiça no caso concreto. Assim, é possível afirmar que na Constituiçâo da República de 1988 fora atribuído reforço ao controle concentrado, uma vez que no seu art. 103 são arrolados os legitimados a requerer tal controle por meio do Supremo Tribunal Federal (STF).

Nesse contexto, em que pese Carvalho (2013), por exemplo, defender a inércia de norma concebida inconstitucional, pois impotente na produção de quaisquer efeitos, é possível perceber, diante de casos concretos, que as consequências 
poderão ser desastrosas enquanto ela estiver disponível no ordenamento jurídico. Com efeito, no que tange ao controle concentrado, que será o foco de estudo no presente trabalho, é necessário abordar os efeitos das decisóes exaradas neste âmbito.

Os efeitos das decisóes no controle concentrado são gerais (erga omnes), pois não existiram litigantes com direitos contrapostos em determinado caso concreto (art. 102, $\$ 2^{\circ}$, da Constituição da República de 1988); vinculantes, pois tal decisão vincula os magistrados no julgamento de casos concretos, e a Administração Pública em seus atos (art. 102, $\$ 2^{\circ}$, da Constituição da República de 1988); retroativos (ex tunc, ab initio, ex origine), destarte a norma impugnada tornar-se sem efeito, desde a raiz (origem); ou prospectivos (ex nunc, pro futuro, a posteriori), amparados na Lei n. 9.868/1999 e praticados em alguns momentos pelo STF, conforme exemplificado adiante neste trabalho.

\subsection{Da modulação dos efeitos temporais das decisóes no controle concentrado de constitucionalidade}

Depreende-se do art. 27 da Lei n. 9.868/1999 (BRASIL, 1999), que dispóe sobre o processo e julgamento da ação direta de inconstitucionalidade e da ação declaratória de constitucionalidade perante o STF - duas das açóes reservadas pelo ordenamento jurídico ao controle concentrado, sendo a primeira analisada por amostragem adiante -, que a regra é a retroatividade na declaração de inconstitucionalidade de lei ou ato normativo. Todavia, por motivos de segurança jurídica ou de excepcional interesse social, poderá o STF (BRASIL, 1999), "por maioria de dois terços de seus membros, restringir os efeitos daquela declaração ou decidir que ela só tenha eficácia a partir de seu trânsito em julgado ou de outro momento que venha a ser fixado", o que é conhecido pela jurisprudência e doutrina a que se teve acesso como a modulação dos efeitos temporais ou declaração de inconstitucionalidade com eficácia restritiva e limitativa. Portanto, na acepção de Carvalho (2013) conclui-se que a regra ao exarar decisóes judiciais é atribuir o efeito ex tunc - declarando a inconstitucionalidade desde a criação da norma -, porém circunstâncias atípicas possibilitam à Suprema Corte atribuir efeito ex nunc - pró-futuro.

Por se tratar de decisão judicial, é imprescindível a fundamentação jurídica adequada quando conceder ou negar a modulação dos efeitos temporais, uma vez que estarão consignadas na decisão as circunstâncias excepcionais e extraordinárias que ensejaram a mitigação dos efeitos da decisão no tempo. Ademais, sabe-se que a decisão oriunda do STF em sede do controle concentrado de constitucionalidade deve ser submetida ao art. 93, inciso IX da Constituição da República de 1988, ou seja, carece da devida fundamentação. 
Dessa maneira, Abboud (2018) defende que além da fundamentação da decisão judicial (art. 93, inciso IX da Constituição da República de 1988) é imprescindível que o STF aponte os direitos fundamentais em debate que em determinada oportunidade foram protegidos pela limitação dos efeitos temporais. Tal registro pelo STF é primordial, pois a referida limitação tende a ser positiva em proteger determinados direitos fundamentais em detrimento de outros (que não terão essa mesma sorte).

Carvalho (2013) e Bulos (2017) entendem que a modulação dos efeitos temporais deve ser medida excepcional, a fim de não desvirtuar a sistemática do controle de constitucionalidade. Para o último doutrinador, tal limitação (defendida por ele como princípio), permite ao STF, in verbis:

[...] dosar os efeitos retroativos (ex tunc) da decisão abstrata de normas; manipular os efeitos gerais (erga omnes) da decisão abstrata, limitando-lhe os efeitos temporais. Em vez de nulificar, ex origine, todos os atos praticados com base na lei declarada inconstitucional, o tribunal confere à sentença eficácia ex nunc. Como tais efeitos voltam-se para o futuro, não é possível haver retroatividade nem repristinaçáo; - fazer uma ponderação entre as normas declaradas inconstitucionais e as normas constitucionais aferidoras de valores supremos, tais como a moralidade, a boa-fé, a coisa julgada, a razoabilidade, a irredutibilidade de vencimentos, a proibição do enriquecimento ilícito, a primazia dos valores decorrentes da cláusula do devido processo legal etc.; e driblar as consequências gravosas de um nocivo formalismo cego (BULOS, 2017, p. 214).

Com efeito, não é possível invocar a modulação dos efeitos temporais de modo irrestrito, por tratar-se de circunstância excepcional, uma vez que enseja evidenciar e fundamentar grave risco à segurança jurídica ou às questóes de relevante interesse social.

Isso posto, a modulação dos efeitos temporais é medida que se impóe, a fim de evitar-se o caos jurídico. Abboud (2018, p. 629) reforça que "a modulação de efeitos deve ser admitida, objetivando possibilitar a preservação do sistema constitucional", por considerar que "a declaraçấo de desconformidade com a Constituição, com efeitos ex tunc, pode gerar situaçóes de inconstitucionalidade mais danosas e graves que a própria inconstitucionalidade contida da lei” (2018, p. 629), maculando assim os princípios da segurança jurídica e da boa-fé objetiva.

Nessa linha de raciocínio, insta trazer suscintas consideraçóes delimitadas pelo doutrinador Barroso (2009) sobre a argumentação jurídica. Argumentar é 
expor determinada concepção, que deve ser seguida de teses que contribuam para sua defesa. Assim, expor argumentos e fundamentá-los é elemento imprescindível nas decisóes judiciais. Ora, como saber se determinada decisão judicial é legítima e controlável sem poder constatar a linha de raciocínio conduzida pelo magistrado?

Aduz Cavalcante (2018) que restringe os efeitos temporais das decisóes judiciais em matéria tributária é tema muito sensível e sem consenso na doutrina e jurisprudência, por tratar-se de causas que geralmente envolvem grandes vultos e podem acarretar diversas consequências aos polos da relação jurídico-tributária. Com efeito, podemos destacar que a modulação dos efeitos temporais tem criado relevo nos últimos tempos em que o STF tem incluído em pauta assuntos importantes no âmbito do Direito Tributário, e até mesmo fixando diversas teses de repercussão geral que sequer possuem previsão de julgamento.

De modo exemplificativo, no bojo do Recurso Extraordinário (RE) 574706, com repercussão geral reconhecida, o STF considerou inconstitucional a inclusão do ICMS na base de cálculo do PIS/COFINS. Contudo, nada fora consignado sobre a modulação de efeitos temporais. Ora, se tal decisão produzisse seu efeito natural, retroagiria para abarcar os recolhimentos pretéritos realizados pelos contribuintes, podendo ocasionar prejuízos aos cofres públicos em casos de restituição. O portal do STF, em notícia publicada em 15 de março de 2017, registrou:

Quanto à eventual modulação dos efeitos da decisão, a ministra Cármen Lúcia explicou que não consta no processo nenhum pleito nesse sentido, e a solicitação somente teria sido feita da tribuna do STF pela Procuradoria da Fazenda Nacional. Não havendo requerimento nos autos, não se vota modulação, esclareceu a relatora. Contudo, ela destacou que o Tribunal pode vir a enfrentar o tema em embargos de declaração interpostos com essa finalidade e trazendo elementos para a análise (SUPREMO TRIBUNAL FEDERAL, 2019).

Cabe destacar que tal demanda, até o momento da produção deste trabalho, está pendente de julgamento pelo STF.

De outro lado, em artigo jurídico tratando sobre a modulação dos efeitos temporais em decisóes do STF em matéria tributária, Andrade apontou determinados exemplos que nos demonstram falta de padronizaçáo dos critérios de fundamentação da Suprema Corte, além da parcimônia no debate.

Isso posto, cabe registrar, a seguir, a vertente defendida por Abboud:

A modulação não pode ser utilizada de forma discricionária, posto que ela consiste em decisão judicial, logo, precisa atender ao 
disposto no inciso IX do art. 93 da Constituição Federal. Em outros termos, se a modulaçáo de efeitos tiver como base tâo somente os argumentos de risco econômico em benefício do Poder Público, essa decisão será nula porquanto carecedora de fundamentaçáo. [...] A modulação não pode ser realizada com base em argumentos consequencialistas como a preservação da higidez das finanças do Estado (ABBOUD, 2018, p. 640-643, grifo nosso).

Entende-se a delicadeza e seriedade do STF em atribuir efeitos prospectivos às suas decisôes judiciais, pois foge-se, nesse caso, da regra geral. Logo, não basta a mera justificativa de cunho econômico-financeiro, conforme também defende Vasques (2013), sendo necessário aprofundar a discussão em tal perspectiva.

Diante do exposto, espera-se da Suprema Corte a apresentação de argumentos defendendo (ou até mesmo indeferindo) a limitação dos efeitos temporais de decisão judicial, em fundamentação exaustiva, de modo a buscar critérios claros e livres de aparente parcimônia nas razóes de decidir.

\subsection{Das razóes de segurança jurídica ou de excepcional interesse social}

Considerando que a Lei n. 9.868/1999 (BRASIL, 1999) possibilita a restrição dos efeitos temporais das decisóes em sede de ADI por razóes de segurança jurídica ou de excepcional interesse social, insta traçar breves apontamentos sobre ambos.

A segurança jurídica pode ser percebida como um mecanismo que preserva a estabilidade das relaçóes jurídicas. Tanto é que na Constituição da República de 1988 (BRASIL, 1988) pode-se destacar o art. 5º inciso XXXVI, que veda ao legislador o prejuízo ao direito adquirido, ao ato jurídico perfeito e à coisa julgada. E no ordenamento jurídico é possível perceber manifestaçôes direcionadas ao administrador e ao intérprete no que se refere à preservação da segurança jurídica.

Nessa acepçáo, Ávila (2019, p. 19) leciona que é possível perceber a segurança jurídica "quando o indivíduo conhece e compreende o conteúdo do Direito, quando tem assegurados no presente os direitos que conquistou no passado e quando pode razoavelmente calcular as consequências que serão aplicadas no futuro relativamente aos atos que praticar no presente". Outrossim, defende o doutrinador que quando não é garantido ao indivíduo que confie nas consequências advindas das previsóes normativas viola-se a sua liberdade, uma vez que deixa de ser tratado com dignidade e passa a ser objeto. Nesse sentido: 
[...] um Direito que é constantemente alterado, em suas previsóes ou em suas consequências, ao sabor das circunstâncias do momento e dos interesses em jogo, resulta inacessível e incompreensível a seus destinatários. [...] Logo se percebe que as condiçôes essenciais do Estado de Direito constituem precisamente as condiçōes essenciais para a preservação e a promoção de uma vida digna e livre: o Direito deve ser conhecido, compreendido, estável, náo contraditório, igualitário, prospectivo e efetivo; deve permitir ao indivíduo ter plena capacidade de viver o presente e conceber o futuro com liberdade - numa palavra: ser de fato, e não apenas verbalmente, tratado como um sujeito e um fim em si mesmo, nunca como simples objeto ou meio a serviço de outros fins, repita-se, por melhores e mais majestosos que estes possam ser (ÁVILA, 2019, p. 15-19).

Em vias conclusivas, utilizando das palavras de Abboud (2018, p. 652),

[...] a segurança jurídica constitui parâmetro constitucional para a limitaçáo dos efeitos da decisão de inconstitucionalidade sempre que os efeitos retroativos possam acarretar lesão aos interesses/direitos dos cidadáos que tinham expectativa de terem suas relaçōes jurídicas regulamentadas pela lei revogada.

E no tocante às razóes de interesse social, pode-se afirmar que são questôes atreladas aos direitos fundamentais da sociedade, que quando entram em rota de colisão com a inconstitucionalidade que está a se declarar, ensejará a limitação dos efeitos temporais.

Isso posto, vale destacar a diferença existente entre interesse público e interesse social, sendo apenas este último privilegiado pelo legislador ordinário. Assim sendo, justificativas como a manutenção da arrecadaçáo, garantia dos poderes fiscalizatórios, rombo aos cofres públicos etc., não poderão fundamentar de maneira uníssona a modulação dos efeitos temporais das decisóes do STF.

Nesse cenário, e ainda valendo-se das valiosas liçóes de Abboud:

[...] a expressão preservação de excepcional interesse social, deve ser interpretada conforme a Constituição, objetivando garantir que a modulação de efeitos seja utilizada como instrumento para preservaçấo de direitos fundamentais do cidadão. Ademais, fica vedada qualquer modulação com base em interesse público posto que a própria lei destacou a admissibilidade da limitação de efeitos unicamente em prol do interesse social. [...] Ao 
refutarmos a utilizaçáo dos argumentos consequencialistas, nâo se está aqui refutando a necessidade de o STF preocuparse com as consequências sociais e econômicas de suas decisôes. Todavia, essa preocupação não pode consistir na motivação de sua decisão e, principalmente, ela não pode ser usada para afastar a questão jurídico-constitucional que incidiria no caso. Ou seja, as consequências da decisão não podem consistir em subterfúgio para o STF afastar-se da legalidade vigente ao proferir decisóes com modulação de efeitos. [...] Vale dizer, é vedado ao STF realizar a modulaçáo de efeitos com base em argumentos vagos e imprecisos ou com o intuito de privilegiar o Poder Público (ABBOUD, 2018, p. 642-648).

Portanto, não basta ao STF, somente restringir os efeitos temporais das declaraçóes de inconstitucionalidade, mas necessariamente fundamentar as razóes justificadoras atinentes à segurança jurídica e à manutenção do interesse social.

\section{Da necessidade de convênio interestadual para a concessáo de benefícios fiscais no âmbito do ICMS}

Dispóe o art. 155, inciso XII, alínea "g" da Constituição da República de 1988, in verbis:

Art. 155. Compete aos Estados e ao Distrito Federal instituir impostos sobre: II - operações relativas à circulação de mercadorias e sobre prestaçōes de serviços de transporte interestadual e intermunicipal e de comunicação, ainda que as operaçōes e as prestações se iniciem no exterior; $\$ 2^{\circ} \mathrm{O}$ imposto previsto no inciso II atenderá ao seguinte: XII - cabe à lei complementar: g) regular a forma como, mediante deliberação dos Estados e do Distrito Federal, isençôes, incentivos e benefícios fiscais serão concedidos e revogados (BRASIL, 1988).

Por conseguinte, estabelece a Lei Complementar n. 24/1975, recepcionada pela ordem constitucional vigente que, in verbis:

Art. $1^{\circ}$ - As isençóes do imposto sobre operaçôes relativas à circulação de mercadorias serấo concedidas ou revogadas nos termos de convênios celebrados e ratificados pelos Estados e pelo Distrito Federal, segundo esta Lei. [...] Art. $2^{\circ}$ - Os convênios a que alude $\mathrm{o}$ art. $1^{\circ}$, serão celebrados em reunióes para as quais 
tenham sido convocados representantes de todos os Estados e do Distrito Federal, sob a presidência de representantes do Governo federal. [...] $\$ 2^{\circ}-\mathrm{A}$ concessão de benefícios dependerá sempre de decisão unânime dos Estados representados; a sua revogação total ou parcial dependerá de aprovação de quatro quintos, pelo menos, dos representantes presentes. Art. $4^{\circ}-$ Dentro do prazo de 15 (quinze) dias contados da publicação dos convênios no Diário Oficial da Uniáo, e independentemente de qualquer outra comunicação, o Poder Executivo de cada Unidade da Federação publicará decreto ratificando ou não os convênios celebrados, considerando-se ratificação tácita dos convênios a falta de manifestação no prazo assinalado neste artigo (BRASIL, 1975).

Isso posto, acentuam-se dois pontos que são debatidos na doutrina, a saber: (i) a necessidade de decisão unânime dos Estados representados (ou seja, mais rígido que o quórum da maioria) no âmbito do Conselho Nacional de Política Fazendária (CONFAZ); e (ii) a ratificação do convênio pelos Estados e pelo Distrito Federal. Pressupóe-se que tais medidas sejam salutares para evitar a guerra fiscal, e por conseguinte manter intacto o federalismo que é um dos pilares do nosso Estado Democrático de Direito. Com efeito, reiterando com as liçóes de Carrazza, in verbis:

A Constituição exige que todos os Estados-membros da Federação, bem assim o Distrito Federal, se coloquem de acordo, mediante convênio, para que as isençôes de ICMS surjam ou venham abolidas. Este ditame visa evitar a "guerra fiscal" entre as diversas regiōes do País, que são muito díspares, já que, algumas, são industrializadas, outras não; poucas são prósperas; a maioria, nem tanto. Só o consenso entre todas as pessoas políticas interessadas - consubstanciado no convênio -, abre caminho à outorga ou retirada de isençóes de ICMS (CARRAZZA, 2010, p. 933).

Considerando que o CONFAZ não é órgão legislativo, e o que é produzido pelas unidades federadas é apenas uma deliberação, é necessária a ratificação por meio da Assembleia Legislativa ou, no caso do Distrito Federal, por sua Câmara Legislativa. Há polêmica doutrinária sobre qual seria o meio adequado para a ratificação de convênios (decreto legislativo ou lei estadual/distrital), dada a péssima redação do art. $4^{\circ}$ da Lei Complementar n. 24/1975, já aqui reproduzida.

Pois bem. Descarta-se a possibilidade do decreto executivo - aquele tendente a conceder fiel execuçáo à lei (competência atribuída ao presidente da República no art. 84, inciso IV, da Constituição da República de 1988) -, uma vez que não há lei para se executar, e sim convênio firmado entre as unidades federadas. No 
presente trabalho, filia-se à necessidade do decreto legislativo, norma oriunda do devido processo legislativo (art. 59, inciso IV da Constituição da República de 1988).

Schoueri (2018), apoiado em Roque Antonio Carrazza, leciona que a diferença entre a lei estadual e o processo legislativo estaria apenas na anuência do chefe do Executivo, que no primeiro meio o sanciona e o promulga, diferente do segundo. Contudo, no convênio encontra-se consubstanciado o voto do Chefe do Executivo, formalidade já suficiente para que se possa aceitar o decreto legislativo também como o meio adequado para a ratificação de convênios.

Nas palavras de Carrazza:

[...] para que as isenções de ICMS surjam validamente, é preciso que os Estados e o Distrito Federal celebrem entre si convênios, que, ao depois, para se transformarem em Direito interno de cada uma destas pessoas políticas, deverāo ser por ela ratificados. $\mathrm{O}$ instrumento idôneo da ratificação, longe de ser o decreto do Governador, é o decreto legislativo (estadual ou distrital, conforme o caso). [...] Observamos, ainda, que é preciso que todos os Estados e o Distrito Federal ratifiquem o convênio para que a isenção em tela nasça. Reforçando a ideia, se uma única destas entidades tributantes deixar de fazê-lo, o benefício não surgirá (CARRAZZA, 2010, p. 933-934).

Feitas tais consideraçóes, no próximo tópico serão apresentadas, sob o método da amostragem - uma vez que é impossível ventilar todas no presente trabalho -, as discussóes no âmbito de duas açóes direita de inconstitucionalidade que discutiram a inconstitucionalidade de benefícios fiscais em desrespeito aos ditames estabelecidos no art. 155, inciso XII, alínea "g" da Constituição da República de 1988 c/c a Lei Complementar n. 24/1975, mais precisamente na fundamentação e debate adotados pela Suprema Corte para decretar a modulação dos efeitos temporais destas decisóes.

\section{Efeitos prospectivos em duas ADI que declararam a inconstitucionalidade de leis estaduais sobre benefício fiscal do ICMS}

\subsection{ADI 4.481/PR}

$\mathrm{Na}$ ação direta de inconstitucionalidade n. 4.481/PR, ajuizada pela Confederação Nacional da Indústria, teve o intuito de atacar, dentre outros, dispositivos da 
Lei paranaense n. 14.985 de 06 de janeiro de 2006 que possibilitava o pagamento parcelado em 1/48 avos de mercadorias/bens importados e desembaraçados no Estado desde que destinados ao ativo permanente; e escrituração de créditos na conta gráfica do estabelecimento importador em algumas hipóteses descritas no referido diploma. O debate instaurou-se em sessão plenária de 11 de março de 2015, ou seja, a norma produziu efeitos por aproximadamente 9 anos.

Pois bem. Foram trazidas as razões do relator ministro Luís Roberto Barroso de que a concessão unilateral pelas unidades federadas de benefícios fiscais deflagaria a guerra fiscal, por atrair empreendimentos e capital para o Estado concedente em detrimento dos demais. Assim, considerou que a concessão de benefícios fiscais, via parcelamento ou com redução do valor do tributo a pagar, sem anuência do convênio interestadual afronta o art. $155, \$ 2^{\circ}$, XII, g, da CR/1988, conforme já decidiu a Suprema Corte em outras ADIs.

No que se refere à modulação de efeitos temporais da decisão, o ministro relator sugeriu, in verbis:

[...] Nấo gera grande surpresa a decisão ora proferida, no sentido da inconstitucionalidade da lei estadual. Por outro lado, a norma em exame vigorou por oito anos, com presunção de constitucionalidade, de modo que a atribuiçáo de efeitos retroativos à declaraçáo de inconstitucionalidade geraria um grande impacto e um impacto injusto para os contribuintes. [...] Observo, por fim, que a modulaçâo, no presente caso, decorre de um juízo de ponderaçăo que não envolve o assim chamado princípio da supremacia da Constituição. A supremacia da Constituição é pressuposto do sistema de controle da constitucionalidade e, por consequência, é imponderável. A ponderaçáo ocorre entre a disposiçáo constitucional tida por violada e os princípios da boa-fé e da segurança jurídica. Pelas razóes já expostas, entendo que devem prevalecer os últimos princípios, atribuindo-se eficácia a esta decisão a partir da data desta sessão (BRASIL, 2015, grifo nosso).

Nesse aspecto, o ministro relator praticou, com excelência, o lecionado por Bulos (2017, p. 215) de que "a nulidade só deve ser afastada se for possível demonstrar, com base numa ponderaçáo concreta, que a declaração de inconstitucionalidade, em seu sentido clássico, sacrificará a segurança jurídica [...]”. Assim, a modulação de efeitos in casu foi defendida tendo em vista os princípios da boa-fé e da segurança jurídica, embasados no art. 27 da Lei n. 9.868/1999.

Interessante destacar que no ministro Joaquim Barbosa, à época relator, aplicou in casu a técnica do art. 12 da Lei n. 9.868/1999 que, em caso de pedido 
de medida cautelar, poderá o feito ser submetido diretamente ao Tribunal para julgamento definitivo, em virtude da relevância da matéria e de especial significado para a ordem social e a segurança jurídica. Assim, consta do debate dos Ministros que a ADI demorou mais que o normal para ser julgada em virtude de tal ocorrência, sendo mais um motivo a se pensar a modulação dos efeitos temporais da decisão, uma vez que não houve pronunciamento em sede cautelar.

Pois bem. Prossegue o ministro relator justificando, com excelência, a necessidade da modulação dos efeitos temporais, nos seguintes termos:

[...] longe de querer fazer a opção que estimule um comportamento de infraçấo à Constituiçẫo, a verdade é que esta lei vigorou por oito anos, portanto, os jurisdicionados e os contribuintes que cumpriram a lei, até porque, enquanto não declarada inconstitucional, vigia o mandamento da sua presunção de constitucionalidade, eu penso que desfazer retroativamente todos esses anos de benefícios seria de um impacto talvez imprevisível e possivelmente injusto em relação, pelo menos, às partes privadas que cumpriram a lei tal como ela foi posta. [...]Qual é a ponderação que se faz? É a ponderação entre a regra da Constituição que foi violada, a que exige a observância de um rito específico, e, do outro lado, a segurança jurídica, a boa-fé, a estabilidade das relaçóes que já se constituíram. Portanto, não se excepciona a incidência da Constituição, na verdade, ponderam-se dois mandamentos constitucionais. Não é o princípio da supremacia da Constituiçáo que está sendo ponderado, o princípio da supremacia da Constituição é imponderável, ele é o pilar do sistema, o que nós estamos fazendo é, dentro da Constituição, ponderando dois valores ou dois dispositivos que têm assento constitucional. E, nestas circunstâncias, eu estarei privilegiando, ao modular, o mandamento da segurança jurídica e da boa-fé, que, a meu ver, milita em favor sobretudo das partes privadas que cumpriram as regras dessa lei (BRASIL, 2015, grifo nosso).

Em seguida, a discussão instaurou-se sobre qual seria o marco temporal para a modulação de efeitos, a saber: a data do julgamento, ou a data da publicação da ata do julgamento, ou a data da audiência/sessão do julgamento, ou a data da publicação do acórdão? A maioria dos debatedores entenderam que o ideal como marco temporal é a data do julgamento, pois é amplamente conhecida e evita-se que outros contribuintes possam utilizar indevidamente o benefício fiscal declarado inconstitucional enquanto aguarda-se a concretizaçáo de algum procedimento formal (ata do julgamento). 
Em viés contrário à maioria, o ministro Marco Aurélio argumentou, in verbis:

Presidente, o pano de fundo é estreme de dúvidas: a guerra fiscal. $\mathrm{O}$ que havia quando da ediçấo da lei? Jurisprudência pacificada do Supremo sobre a inviabilidade de outorga de benefício fiscal, sem o convênio previsto na Carta da República. Mas, não vinga no Brasil o império da lei [...]. Está ficando muito fácil editar diplomas legais à margem da Constituição Federal, porque depois, em passo seguinte, há o concerto do Supremo; mas concerto não com "s", o concerto com "c". Dá-se, naquele período, o dito pelo nâo dito, salva-se a lei em detrimento da Carta da República, como se esta tivesse ficado em suspenso no período, não vigorasse no território nacional. E me assusta muito que se vem, passo a passo, generalizando o instituto da modulaçáo [...]. Fico a imaginar em que caso se deixará de modular a decisão, se, num caso em que houve o desrespeito flagrante, frontal à Constituição, mais do que isso, a reiterados pronunciamentos do Supremo, é implementada a modulação. [...] Não modulo, Presidente (BRASIL, 2015, grifo nosso).

Guarda razóes os argumentos do ministro Marco Aurélio, pois limitar os efeitos da decisão também seria possibilitar a edição de leis estaduais concedendo benefício fiscal de ICMS sem convênio interestadual, pois posteriormente estarão protegidos pela decisão da Suprema Corte, violando assim a boa-fé objetiva. Com efeito, a recíproca é verdadeira, e nesse mesmo aspecto, Abboud afirma que

[...] não pode o Pretório Excelso, em especial no que se refere às questôes tributárias, modular efeitos, porque eventualmente sua decisão poderia acarretar consequências econômicas negativas ao erário. [...] Se o STF julgasse um tributo inconstitucional e, em seguida, modulasse os efeitos (ex nunc), essa decisão seria contrária à boa-fé objetiva porque, em outras palavras, estaria autorizando o Poder Público a praticar ato ilícito (instituir tributo inconstitucional), porque tudo que ele conseguisse auferir com a cobrança do tributo ilegal nunca precisaria ser restituída; ou seja, o STF não pode em suas decisôes corroborar e legitimar uma prática ilícita e desleal do Poder Público. Desse modo, reafirmamos nosso posicionamento contrário à modulação de efeitos quando o tributo é declarado inconstitucional, porque essa decisão se tiver seus efeitos limitados, favorecerá a má 
conduta da Administração, algo contrário à boa-fé objetiva e a todos os demais princípios elencados no art. $37 \mathrm{da} \mathrm{CF} / 1988$, que vinculam indiscutivelmente o Poder Público (ABBOUD, 2018, p. $656-658)^{2}$.

Todavia, insta destacar que no atual sistema tributário em que sobrevivemos - diante da complexidade que se constituiu - é impossível ao contribuinte acompanhar criteriosamente a jurisprudência e o entendimento das decisóes em âmbito administrativo, até mesmo porque, em dado período de tempo, tendem a mudar, considerando aspectos temporais, fáticos e contextuais. Até mesmo considerando que as normas são presumidamente constitucionais, pois promulgadas em viés democrático, com a participação dos representantes do povo e resultado do devido processo legislativo.

Diante do exposto, do extrato de ata consignou-se o julgamento parcialmente procedente do pedido da ADI, por unanimidade, considerando a inconstitucionalidade do benefício fiscal. E concernente à modulaçáo, sem ressalvas ou incrementos dos outros ministros, por maioria, decidiu-se pela produção de eficácia da decisão a partir da sessão plenária.

\subsection{ADI $2.663 / \mathrm{RS}$}

Trata-se de açáo direta de inconstitucionalidade ajuizada pelo governador do Estado do Rio Grande do Sul, com pedido de medida cautelar, que impugnava, dentre outros, o dispositivo da Lei n. 11.743 de 05 de março de 2002 do Estado do Rio Grande do Sul que previa dedução de 50\% do valor de bolsa concedida, no montante do ICMS da empresa que a financiasse aos professores que necessitam de complemento na formação pedagógica, sob argumento de que violava o art. $155, \$ 2^{\circ}$, XII, “g”, da Constituição da República. In casu também fora aplicada a técnica do art. 12 da Lei n. 9.868/1999, pelo ministro Nelson Jobim (relator à época), havendo assim submissão direta da ação ao Tribunal para julgamento definitivo.

Submetida à sessão plenária de 08 de março de 2017, e sendo a ação direta de relatoria do eminente ministro Luiz Fux, o voto é embalado por noçôes gerais do federalismo, no sentido de que o pluralismo político permite a atuação livre dos Estados, porém, no âmbito do ICMS há uma limitação constitucional a fim de preservar o equilíbrio horizontal na tributação, evitando-se a guerra fiscal, uma vez que o ICMS é tributo fonte de grande parte dos recursos dos Estados. Outrossim, o ministro arrolou julgados da Suprema Corte uníssonos no tocante

2 Nesse mesmo sentido defende o professor Humberto Ávila, em diversos momentos de sua obra constante das referências do presente trabalho. 
à inconstitucionalidade das leis estaduais que desatendem o convênio estadual na concessão de benefícios fiscais de ICMS. No que se refere à limitação dos efeitos da decisão, de forma simplória, consignou, in verbis:

Por fim, mercê das razóes de segurança jurídica dos contribuintes alcançados pelas normas ora analisadas, proponho que sejam modulados os efeitos da decisão de inconstitucionalidade do art. $3^{\circ}$ da norma impugnada, conferindo-lhes efeitos ex nunc, nos termos do art. 27 da Lei n. 9.868/99, a contar da publicaçáo da ata do presente julgamento (BRASIL, 2017).

Em um primeiro momento, data máxima venia de maneira equivocada, foi ventilado no debate, por alguns dos ministros, uma simpatia pelo estabelecido pela Lei n. 11.743 de 05 de março de 2002 do Estado do Rio Grande do Sul, de forma que náo se tratava de benefício fiscal propriamente dito, e sim de incentivo para o financiamento da classe dos professores, cogitando excepcionar a jurisprudência já consolidada pela Corte. Nesse sentido, o seguinte trecho do ministro Marco Aurélio:

Náo se trata de guerra fiscal, mas de simples contrapartida, de simples incentivo a concessão de bolsa. A iniciativa privada adentra campo que poderia estar ocupado pelo próprio Estado: o alusivo ao aprimoramento da classe sacrificada a que me referi - dos professores. É preciso acordar um dia para a necessidade de culto à educaçấo. Julgo improcedente o pedido formalizado pelo Governador do Estado do Rio Grande do Sul na inicial desta ação direta de inconstitucionalidade (BRASIL, 2017).

Concernente à limitação dos efeitos da decisão, de forma breve e desacompanhado das consideraçôes dos demais, o ministro Luís Roberto Barroso pronunciou-se nos seguintes termos:

Portanto, Presidente, ainda que tenha simpatia pela lei, acho que é um risco abrirmos essa fresta numa jurisprudência consolidada. Por essa razão, ligeiramente a contragosto, eu estou acompanhando a declaração de inconstitucionalidade deste art. $3^{\circ}$. Apenas com uma ressalva, que me parece natural - é uma lei que está vigendo há 15 anos e não é uma inconstitucionalidade chapada -, portanto, eu náo acho que quem tenha se beneficiado possa ser compelido a devolver dinheiro ou a pagar tributo. Portanto, a minha decisáo é com efeitos prospectivos (BRASIL, 2017, grifo nosso). 
Do extrato de ata foi possível constatar o julgamento parcialmente procedente do pedido da ADI, considerando inconstitucional o benefício fiscal concedido, com efeito ex nunc, a partir da publicação da ata de julgamento. Com efeito, é possível perceber que nesta ação também não foram debatidas, de modo detalhado, as razóes justificadoras para a modulação dos efeitos temporais da decisão.

Nesse ponto, Abboud (2018, p. 636), ao lecionar sobre a modulação dos efeitos temporais, entende que "toda decisão que realize o controle de constitucionalidade, juntamente com a modulação de efeitos, deverá obrigatoriamente, em sua fundamentação, indicar em que medida e em quais direitos fundamentais essa limitação de efeitos pretende tutelar".

Por conseguinte, náo bastaria apenas a mençáo da proteção à segurança jurídica com vistas à modular os efeitos temporais da referida decisão, esperando ademais da Suprema Corte, ou seja, apontando em quais medidas a não restrição de efeitos atacaria o sentimento de estabilidade que o contribuinte possui com o ordenamento jurídico, além de averiguar a crítica aventada pelo eminente ministro Marco Aurélio na ADI 4.481/PR (detalhada no item 3.1 do presente trabalho), isto é, continuar a aplicar a técnica excepcional da Lei n. 9.868/1999 poderia ensejar novos benefícios fiscais sem anuência do convênio interestadual.

\section{Consideraçóes finais}

Diante do exposto, percebe-se que tem sido utilizado, como argumento para a modulação dos efeitos temporais das açôes apresentadas neste trabalho, apenas a alegação do resguardo à segurança jurídica aliado ao lapso temporal de produção de efeitos de norma inconstitucional, por violação do art. $155, \S 2^{\circ}$, XII, "g", da Constituição da República.

Difunde-se a presunção de constitucionalidade das normas e, aliado à complexidade do sistema tributário, é normal que o contribuinte se utilize de benefícios fiscais concedidos por normas oriundas das unidades federadas, embasado também pela boa-fé objetiva, presumindo-se a conduta proba do poder público. Por conseguinte, instaura-se a eterna discussão, pois há de um lado a astuciosa norma da unidade federada que concede benefícios fiscais sem observar as formalidades necessárias (em nome da guerra fiscal), e de outro lado o resguardo à segurança jurídica do contribuinte que utilizou da determinada norma no presente, e provisionou as consequências que lhe seriam apresentadas.

Ora, defendeu-se no presente trabalho que a limitação dos efeitos temporais é mecanismo autorizado pelo legislador em hipóteses excepcionais e extraordinárias, uma vez que contraria a sistemática do controle de constitucionalidade. 
Assim, a referida modulação faz-se poderosa e imprescindível para que sejam resguardados os valores mínimos de um Estado de Direito, devendo ser tratada, data máxima venia, com mais asseio pela nossa Suprema Corte. Contudo, destaca-se que a utilização de tal mecanismo em todas as situaçóes possíveis tende a afetar a supremacia constitucional, pois mesmo que a inconstitucionalidade seja chapada, a Suprema Corte é a guardiã da lei maior.

Diante do exposto, é imprescindível que o acórdão da Suprema Corte seja consubstanciado em detalhada fundamentação e exaustivo debate sobre as razóes de segurança jurídica e de interesse social que ensejam a modulação dos efeitos temporais de suas decisóes que declararam a inconstitucionalidade de leis estaduais que concederam benefício fiscal de ICMS com a ausência de convênio interestadual. Pois, é mandamento constitucional a fundamentação das decisôes judiciais, conforme preceitua a melhor doutrina a que se teve acesso, e por tratar-se de tema que reflete na guerra fiscal entre os Estados da federaçáo provocada no âmbito do ICMS.

\section{Referências}

ABBOUD, G. Processo constitucional brasileiro. 2a ed. rev., atual, e ampl. São Paulo: Thomson Reuters Brasil, 2018.

ANDRADE, F. M. A (in)aplicação dos efeitos prospectivos na jurisprudência do STF em matéria tributária. Disponível em: http://www-old.andrade.adv.br/site/LinkClick.aspx?fileticket=SO9cKiaBATk\%3D\&tabid=80\&language $=$ pt $-\mathrm{BR}$. Acesso em: 16 mar. 2021.

ÁVILA, H. Constituição, liberdade e interpretação. São Paulo: Malheiros, 2019.

BARROSO, L. R. Curso de direito constitucional contemporâneo: os conceitos fundamentais e a construção do novo modelo. Sáo Paulo: Saraiva, 2009.

BONAVIDES, P.. Curso de direito constitucional. 8a ed. rev., atual., e ampl. São Paulo: Malheiros, 1999.

BULOS, U. L. Direito constitucional ao alcance de todos. 7 a ed. rev. e atual. até a Emenda Constitucional n. 95, de 15-12-2016, e os últimos julgados do Supremo Tribunal Federal. São Paulo: Saraiva, 2017.

BRASIL. [Constituição (1988)] Constituição da República Federativa do Brasil de 1988. Brasília, DF: Presidência da República, [2021]. Disponível em: http:// www.planalto.gov.br/ccivil_03/constituicao/constituicao.htm. Acesso em: 25 dez. 2019. 
BRASIL. Lei Complementar n. 24, de 7 de janeiro de 1975. Dispóe sobre os convênios para a concessão de isençóes do imposto sobre operaçóes relativas à circulação de mercadorias, e dá outras providências. 07 de janeiro de 1975. Disponível em: http://www.planalto.gov.br/ccivil_03/LEIS/LCP/Lcp24.htm. Acesso em: 25 dez. 2019.

BRASIL. Lei n. 9.868, de 10 de novembro de 1999. Dispóe sobre o processo e julgamento da ação direta de inconstitucionalidade e da ação declaratória de constitucionalidade perante o Supremo Tribunal Federal. 10 de novembro de 1999. Disponível em: http://www.planalto.gov.br/ccivil_03/leis/19868.htm. Acesso em: 25 dez. 2019.

BRASIL. Supremo Tribunal Federal. Ação direta de inconstitucionalidade 4.481 Paraná. Relator: Min. Roberto Barroso. Diário de Justiça Eletrônico. Brasília, 19 de maio de 2015. Disponível em: http://portal.stf.jus.br/processos/downloadPeca. asp?id=306842598\&ext=.pdf. Acesso em 01 jan. 2020.

BRASIL. Supremo Tribunal Federal. Ação direta de inconstitucionalidade 2.663 Rio Grande do Sul. Relator: Min. Luiz Fux. Diário de Justiça Eletrônico. Brasília, 29 de maio de 2017. Disponível em: http://portal.stf.jus.br/processos/downloadPeca.asp?id=311896171\&ext=.pdf. Acesso em 01 jan. 2020.

CARRAZZA, R. A. Curso de direito constitucional tributário. 26a ed. rev., ampl. e atual. até a Emenda Constitucional n. 64/2010. São Paulo: Malheiros.

CARVALHO, K. G. Direito constitucional: teoria do estado e da constituição. Vol. 1. $20^{\mathrm{a}}$ ed. rev., atual., e ampl. Belo Horizonte: Del Rey, 2013.

CAVALCANTE, D. L. Reflexóes sobre a modulação dos efeitos das decisóes do STF em matéria tributária. Revista do Programa de Pós-graduação em Direito UFC. Fortaleza, v. 38, n. 1, p. 379-390, jan./jun. 2018. Disponível em: http://www. periodicos.ufc.br/nomos/article/view/32678/73327. Acesso em: 16 mar. 2021.

INCLUSÃO DO ICMS na base de cálculo do PIS/Cofins é inconstitucional. Supremo Tribunal Federal (STF). 15 mar. 2017. Disponível em: http://www.stf. jus.br/portal/cms/verNoticiaDetalhe.asp?idConteudo=338378. Acesso em: 25 dez. 2019.

PARANÁ. Assembleia Legislativa. Lei n. 14.985, de 06 de janeiro de 2006. Dispóe sobre benefício de suspensão do pagamento do ICMS devido nas operaçóes que especifica a estabelecimento industrial paranaense nas importaçóes por aeroportos e portos de Paranaguá e Antonina. Disponível em: http://redir.stf.jus.br/paginadorpub/paginador.jsp?docTP=TP\&docID=789758. Acesso em: 14 abril 2021. 
RIO GRANDE DO SUL. Assembleia Legislativa. Lei n. 11.743, de 5 de março de 2002. (publicada no DOE n. 043, de 6 de março de 2002). Assegura prestação de serviço e possibilita incentivo a empresas que financiarem bolsas de estudo aos professores que necessitam completar a formação pedagógica. Disponível em: http://www.al.rs.gov.br/filerepository/repLegis/arquivos/11.743.pdf. Acesso em: 14 abril 2021.

SCHOUERI, L. E. Direito Tributário. 8. ed. São Paulo: Saraiva Educação, 2018. VASQUES, A. C. B. Segurança jurídica e modulação de efeitos da declaração de inconstitucionalidade: especificidades em matéria tributária. Revista da PGFN, Brasília, DF, v. 3, n. 1, p. 79-100, jan./jul. 2013. Disponível em: https://www. gov.br/pgfn/pt-br/central-de-conteudo/publicacoes/revista-pgfn/ano-iii-numero-5-2013/d5.pdf. Acesso em: 16 mar. 2021. 